\title{
Pengaruh Rock Phosphate dan Dolomit terhadap Distribusi Perakaran Tanaman Kelapa Sawit pada Tanah Ultisols
}

\author{
Eko Noviandi Ginting*, Iput Pradiko, Rana Farrasati, and Suroso Rahutomo \\ Kelompok Peneliti Ilmu Tanah dan Agronomi \\ Pusat Penelitian Kelapa Sawit (PPKS) Medan \\ *Alamat korespondensi: eko.novandy@gmail.com
}

\section{ABSTRACT \\ Effects of rock phosphate and dolomite on oil palm root distribution in Ultisols}

\begin{abstract}
Architecture of oil palm roots may vary under different soil types due to variation in physical, chemical, and biological soil properties. This study investigated effects of rock phosphate and dolomite on oil palm root distribution in Ultisol. Site study was at Aek Pancur, Tanjung Morawa, North Sumatra. Treatments applied on 19 years old oil palms were control (K), $1 \mathrm{~kg}$ dolomite/palm (D), $1 \mathrm{~kg}$ rock phosphate/palm (RP), and $1 \mathrm{~kg}$ dolomite $+1 \mathrm{~kg}$ rock phosphate/palm (D+RP). The observation was conducted at $1 / 6$ part of weeding circle, with radius of $0-4.5 \mathrm{~m}$ from the basal stem at $0-40 \mathrm{~cm}$ soil depth. The study showed that the roots were distributed dominantly in radius of 0-1 $\mathrm{m}$ from the basal stem. Furthermore, the density of primary roots was higher in $20-40 \mathrm{~cm}$ than in 0-20 cm, while higher density of secondary and tertiary roots was found in $0-20 \mathrm{~cm}$ soil depth. Rock phosphate had increased soil $\mathrm{pH}$ which in turn increased $\mathrm{P}, \mathrm{K}$, and $\mathrm{Mg}$ content in roots. Total root density $\left(\mathrm{g} / \mathrm{dm}^{3}\right)$ under RP treatment was $47 \%, 16 \%$, and $32 \%$ higher compared to $\mathrm{K}, \mathrm{D}$, and $\mathrm{D}+\mathrm{RP}$ treatments, respectively. In other words, RP application improved soil chemical properties, stimulated root growth, and increased plant nutrients uptake.
\end{abstract}

Keywords: Dolomite, Oil palm, Root distribution, Rock phosphate

\begin{abstract}
ABSTRAK
Karakteristik morfologi akar tanaman kelapa sawit bervariasi pada berbagai jenis tanah yang disebabkan oleh perbedaan sifat fisik, kimia dan biologi tanah. Penelitian ini dilakukan untuk mengetahui pengaruh pemberian Rock phosphate dan dolomit terhadap karakteristik akar (perkembangan dan distribusi akar tanaman) pada tanah Ultisol. Penelitian dilaksanakan di Kebun Percobaan Aek Pancur milik Pusat Penelitian Kelapa Sawit, Tanjung Morawa, Sumatera Utara. Perlakuan yang dicobakan pada tanaman berumur 19 tahun dalam penelitian ini adalah $\mathrm{K}$ (kontrol); $\mathrm{D}$ (Dolomit dengan dosis $1 \mathrm{~kg} /$ pohon); RP (Rock Phosphate dengan dosis $1 \mathrm{~kg} /$ pohon); dan $\mathrm{D}+\mathrm{RP}$ (Dolomit dan RP dengan dosis masing-masing $1 \mathrm{~kg} /$ pohon). Pengamatan dilakukan pada $1 / 6$ bagian piringan dengan radius 0-4,5 $\mathrm{m}$ dari pangkal pohon dan kedalaman 0-40 cm. Distribusi perakaran tertinggi terdapat pada radius 0-1 $\mathrm{m}$ dari pangkal pohon. Akar primer lebih banyak ditemukan pada kedalaman 20-40 cm, sedangkan akar sekunder dan tersier lebih dominan pada kedalaman 0-20 cm. Aplikasi RP meningkatkan $\mathrm{pH}$ tanah sekaligus kandungan $\mathrm{P}, \mathrm{K}$, dan $\mathrm{Mg}$ pada perakaran. Total kerapatan akar $\left(\mathrm{g} / \mathrm{dm}^{3}\right)$ pada perlakuan RP berturut-turut $47 \%, 16 \%$, dan $32 \%$ lebih tinggi dibandingkan perlakuan K, D, dan D+RP. Aplikasi RP pada penelitian ini dapat memperbaiki sifat kimia tanah, merangsang pertumbuhan akar, dan serapan hara tanaman.
\end{abstract}

Kata Kunci: Dolomit, Distribusi perakaran, Kelapa sawit, Rock phosphate

\section{PENDAHULUAN}

Akar merupakan organ tanaman yang memainkan peran penting dalam pertumbuhan dan perkembangan tanaman (Lynch, 2011). Beberapa fungsi vital akar tanaman yang paling umum adalah berperan dalam penyerapan air dan hara (Yahya et al., 2010), serta sebagai penopang tegaknya tanaman 
(Jourdan et al., 2000; Intara et al., 2018). Selain berfungsi untuk menyerap air dan hara dari dalam tanah, akar juga berfungsi untuk menyimpan cadangan karbohidrat non-struktural (Evert, 2006). Kemampuan akar tanaman untuk menyerap air dan hara dari dalam tanah erat kaitannya dengan proses fotosintesis tanaman (Dubrovsky \& Laskowski, 2017). Akar juga berperan dalam pergerakan karbon dan energi yang berasal dari kanopi ke dalam tanah, hal tersebut menggambarkan bahwa akar juga berperan dalam siklus biogeokimia karbon (Koh \& Wilcove, 2008; Smith et al., 2012).

Karakteristik akar atau root characteristic di dalam tanah sangat bervariasi antara satu jenis tanah dengan jenis tanah lainnya. Kondisi ini dipengaruhi oleh beberapa faktor termasuk sifat fisik tanah yang meliputi struktur tanah, distribusi partikel tanah, distribusi ukuran pori tanah, kemampuan tanah menyimpan air dan udara, dan komposisi faktor biotik di dalam tanah (Ralisch \& Conti, 2012; Li et al., 2015a; Blume et al., 2016; Ren et al., 2018). Selain sifat fisik, sifat kimia tanah juga akan memengaruhi perkembangan akar tanaman (Nyoki \& Ndakidemi, 2018). Sebagai contoh, pada tanahtanah masam seperti ordo tanah Ultisols yang sebarannya sekitar 25\% dari total luasan darat Indonesia (Sipayung et al., 2014; Syahputra et al., 2015), sistem perakaran tidak berkembang karena kelarutan unsur $\mathrm{Al}$ yang cukup tinggi akibat $\mathrm{pH}$ tanah yang rendah (Yahya et al., 2010; Sun et al., 2011).

Selain secara langsung memengaruhi perkembangan perakaran tanaman, kelarutan $\mathrm{Al}$ yang tinggi dapat meningkatkan fiksasi Fosfor $(\mathrm{P})$, sehingga kadar $\mathrm{P}$ tersedia yang rendah umum ditemukan pada tanah masam (Fitriatin et al., 2014; Husnain et al., 2014). Fosfor memegang peran penting sebagai komponen molekuler dalam ATP, ADP, NAD dan NADPH yang mengontrol berbagai reaksi dalam tanaman seperti fotosintesis, respirasi, sintesis protein dan asam amino serta transportasi hara (Boroomand \& Grouh, 2012). Fosfor juga merupakan hara makro yang sangat penting bagi perkembangan akar, terutama pada awal pertumbuhan (Redzuan et al., 2013). Defisiensi P akan mempengaruhi pertumbuhan dan mengurangi produktivitas tanaman. Dalam upaya menjaga kelangsungan berbagai proses dalam tanaman serta meningkatkan $\mathrm{P}$ tersedia untuk perkembangan akar, maka diperlukan aplikasi pupuk P. Selain itu, aplikasi pupuk $\mathrm{P}$ dapat memperbaiki sifat kimia tanah melalui perbaikan $\mathrm{pH}$ tanah (Anggraini et al., 2009).
Salah satu sumber hara $\mathrm{P}$ yang diaplikasikan pada perkebunan kelapa sawit di Indonesia adalah Rock Phosphate (RP). Harga yang relatif bersaing dan cukup ekonomis dibandingkan pupuk $\mathrm{P}$ lainnya merupakan pertimbangan utama dari pekebun sawit untuk menggunakan RP. Selain itu, RP merupakan sumber $\mathrm{P}$ yang efektif bagi tanah masam seperti Ultisol (Adorolo et al., 2015). Sementara itu, untuk memperbaiki $\mathrm{pH}$ tanah, pekebun di Indonesia umumnya mengaplikasikan Dolomit $\left(\mathrm{CaMg}\left(\mathrm{CO}_{3}\right)\right)$. Disamping fungsinya untuk memenuhi kebutuhan $\mathrm{Mg}$ tanaman. Dolomit secara luas digunakan karena memberikan efek pengapuran pada tanah (Shamshuddin et al., 2009). Namun demikian, informasi terkait hubungan perakaran tanaman kelapa sawit dengan aplikasi RP dan Dolomit masih terbatas. Oleh karena itu, penelitian ini bertujuan untuk mengkaji dampak aplikasi RP dan Dolomit terhadap perkembangan dan distribusi akar tanaman kelapa sawit pada tanah Ultisol.

\section{BAHAN DAN METODE}

Penelitian ini dilaksanakan di Kebun Percobaan Aek Pancur milik Pusat Penelitian Kelapa Sawit yang berada di Tanjung Morawa, Deli Serdang, Sumatera Utara. Tanaman kelapa sawit yang digunakan dalam penelitian ini berumur 19 tahun yang ditanam pada areal dengan topografi datar sampai bergelombang dan dengan ordo tanah Ultisols dengan subgroup dominan Typic Hapludults. Berdasarkan data curah hujan kurun waktu 1994 - 2018, tipe curah hujan di areal kajian adalah curah hujan ekuatorial dengan rerata curah hujan tahunan $2.165 \mathrm{~mm} /$ tahun. Terdapat 4 perlakuan pada penelitian ini, yaitu kontrol (tidak ada aplikasi RP atau Dolomit), aplikasi $1 \mathrm{~kg}$ Dolomit/tanaman (D), aplikasi $1 \mathrm{~kg}$ Rock Phosphate/tanaman (RP), dan aplikasi $1 \mathrm{~kg}$ Dolomit dan $1 \mathrm{~kg}$ Rock Phosphate/tanaman (D+RP). Masingmasing perlakuan terdiri dari 1 pohon kelapa sawit dan tidak menggunakan ulangan. Tanaman yang dipilih merupakan tanaman yang relatif seragam dengan jarak minimal satu pohon (selang 1 pohon). Kandungan hara RP yang diaplikasikan dalam penelitian ini adalah $27 \% \mathrm{P}_{2} \mathrm{O}_{5}$. Sementara itu, kandungan hara Dolomit yang diaplikasikan dalam penelitian ini adalah 20\% MgO dan 30\% CaO.

Rock Phosphate, Dolomit, dan kombinasi keduanya diaplikasikan dengan cara ditabur merata pada $1 / 6$ piringan pohon sampai dengan jarak 4,5 meter dari pangkal batang (Gambar 1). Sementara itu, untuk meminimalkan adanya pengaruh 
pemupukan sebelumnya terhadap perkembangan akar tanaman, kegiatan pemupukan pada pohon contoh tersebut telah dihentikan selama satu tahun sebelum penelitian dilaksanakan. Pengamatan terhadap perkembangan akar sebagai pengaruh dari perlakuan dilakukan satu tahun setelah perlakuan diaplikasikan. Perkembangan perakaran tanaman diamati pada beberapa tempat, yaitu (i) kedalaman 0 - $20 \mathrm{~cm}$ dan 20 - $40 \mathrm{~cm}$ pada jarak 1 meter dari pangkal batang, (ii) kedalaman $0-20 \mathrm{~cm}$ dan $20-40$

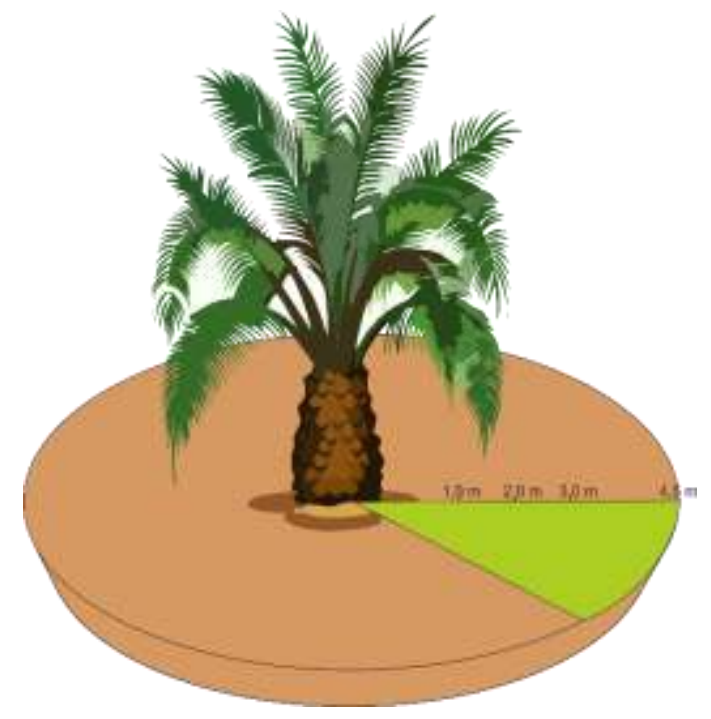

cm pada jarak 2 meter dari pangkal batang, (iii) kedalaman $0-20 \mathrm{~cm}$ dan $20-40 \mathrm{~cm}$ pada jarak 3 meter dari pangkal batang, dan (iv) kedalaman 0 $20 \mathrm{~cm}$ dan 20 - $40 \mathrm{~cm}$ pada jarak 4,5 meter dari pangkal batang. Pengambilan contoh akar dilakukan dengan metode potong kue atau dikenal dengan istilah Voronoi Trench (Jourdan \& Rey, 1997). Skema pengambilan akar tersebut disajikan pada Gambar 1 di bawah ini.

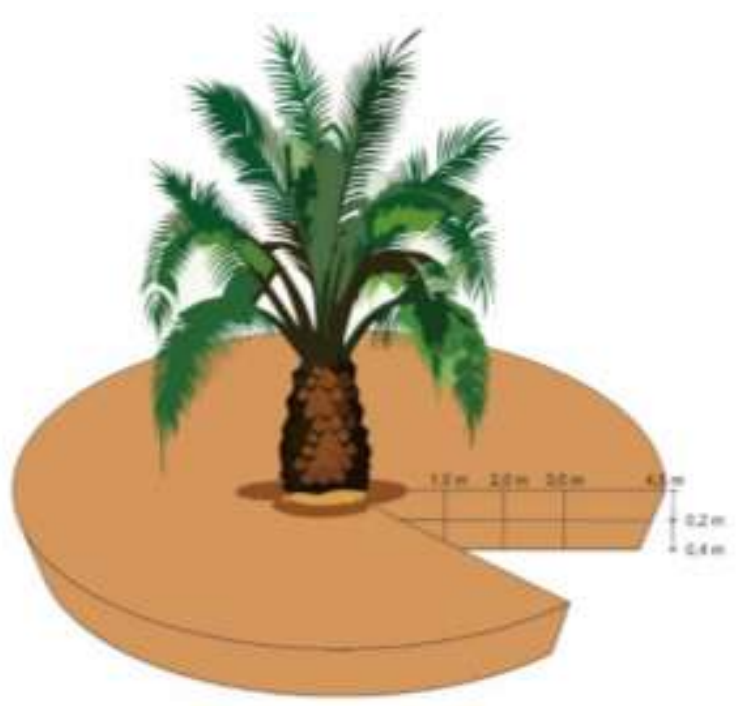

Gambar 1. Metode aplikasi pupuk (kiri) dan pengambilan sampel akar (kanan).

Contoh akar selanjutnya dikelompokkan menjadi 3 kelompok yaitu: (i) akar primer ( $\square>5$ $\mathrm{mm}$ ), (ii) akar sekunder ( $\square$ 2,5- $5 \mathrm{~mm}$ ), dan akar tersier ( $\square<2,5 \mathrm{~mm}$ ) (Marwanto dkk., 2012; Yahya et al., 2010). Selanjutnya, akar pada masing-masing kelompok tersebut dimasukkan ke dalam oven dengan suhu $60^{\circ} \mathrm{C}$ hingga beratnya konstan. Untuk mencari nilai distribusi perakaran maka digunakan rumus (Pradiko dkk., 2016) sebagai berikut:

Distribusi perakaran (biomassa)

$$
=\frac{\text { Berat kering akar }(\mathrm{gram})}{\text { Volume tanah }(\mathrm{dm} 3)}
$$

Sementara itu, untuk parameter sifat kimia tanah, contoh tanah diambil secara komposit pada jarak 1; 2; 3; dan 4,5 meter dari batang serta pada kedalaman $\quad 0-20$ dan 20-40 cm. Setelah dikeringanginkan, dilakukan analisis sifat kimia dari sampel tanah. Analisis tanah meliputi $\mathrm{pH}$, dan $\mathrm{P}$ (fosfor), serta analisis laboratorium untuk mengetahui kandungan $\mathrm{N}, \mathrm{P}, \mathrm{K}, \mathrm{Ca}$, dan $\mathrm{Mg}$ pada sampel akar. Data distribusi perakaran dan kadar hara tanah pada masing-masing radius selanjutnya dianalisis secara deskriptif.

\section{HASIL DAN PEMBAHASAN}

\section{pH Tanah dan Ketersediaan P}

Berdasarkan hasil pengamatan, bila dibandingkan dengan kontrol seluruh perlakuan mengalami kenaikan $\mathrm{pH}$ tanah pada bagian topsoil atau permukaan tanah (kedalaman $0-20 \mathrm{~cm}$ ) (Tabel 1). Nilai $\mathrm{pH}$ topsoil tertinggi adalah 4,8 pada perlakuan $\mathrm{D}+\mathrm{RP}$ (aplikasi dolomit dan rock phosphate). Melalui penelitian ini diketahui bahwa rock phosphate memiliki efek pengapuran pada tanah, begitu juga dengan dolomit, diduga karena rock phosphate mengandung $\mathrm{CaCO}_{3}$ (El Zrelli et al., 2018). Hasil temuan serupa juga dilaporkan oleh Danso et al. (2010) yang menyatakan bahwa peningkatan $\mathrm{pH}$ tanah terjadi setelah aplikasi rock phosphate selama 3 tahun. Khusus untuk kelapa sawit, peningkatan $\mathrm{pH}$ tanah pada areal piringan setelah aplikasi rock phosphate juga dilaporkan oleh Abat et al. (2012). Sebaliknya, pH tanah pada lapisan 
subsoil cenderung stabil ( $\mathrm{pH} 3,9$ - 4,3). Hal ini mengindikasikan bahwa perubahan pada sifat kimia tanah melalui aplikasi perlakuan pada penelitian ini cenderung dominan terjadi pada lapisan tanah topsoil. Perubahan sifat kimia tanah yang utamanya terjadi pada topsoil melalui aplikasi dolomit juga dilaporkan oleh Sutarta dkk. (2017), sedangkan Gao et al. (2010) menyatakan bahwa hal tersebut terajadi karena aplikasi pupuk dan bahan amelioran tanah.

Tabel 1. P tersedia dan $\mathrm{pH}$ pada topsoil $(0-20 \mathrm{~cm})$ dan subsoil $(20-40 \mathrm{~cm})$

\begin{tabular}{|c|c|c|}
\hline Perlakuan & $\mathrm{pH}\left(\mathrm{H}_{2} \mathrm{O}\right)$ & $\mathrm{P}(\mathrm{ppm})$ \\
\hline \multicolumn{3}{|c|}{--------- 0 - 20 cm -------- } \\
\hline Kontrol (K) & 4,2 & 4 \\
\hline Rock phosphate (RP) & 4,7 & 8 \\
\hline Dolomit (D) & 4,7 & 4 \\
\hline $\begin{array}{l}\text { Dolomit }+ \text { Rock phosphate } \\
(\mathrm{D}+\mathrm{RP})\end{array}$ & 4,8 & 8 \\
\hline \multicolumn{3}{|c|}{--------- $20-40 \mathrm{~cm}-------$} \\
\hline Kontrol (K) & 4,2 & 3 \\
\hline Rock phosphate (RP) & 4,3 & 5 \\
\hline Dolomit (D) & 3,9 & 4 \\
\hline $\begin{array}{l}\text { Dolomit }+ \text { Rock phosphate } \\
(\mathrm{D}+\mathrm{RP})\end{array}$ & 4,2 & 5 \\
\hline
\end{tabular}

Kandungan $\mathrm{P}$ tersedia pada topsoil dengan perlakuan $\mathrm{D}$ dan $\mathrm{K}$ adalah $4 \mathrm{ppm}$, meningkat dua kali lipat menjadi $8 \mathrm{ppm}$ pada perlakuan RP dan D+RP. Dengan kata lain, kandungan $\mathrm{P}$ tersedia pada topsoil cenderung mengikuti input dari rock phosphate. Hasil tersebut menjelaskan bahwa sebagian $\mathrm{P}$ tersedia dari perlakuan $\mathrm{RP}$ dan $\mathrm{D}+\mathrm{RP}$ dipertahankan pada pool ikatan lemah, dan masih dapat diekstrak dengan larutan Bray 2.

Seperti yang dikatakan sebelumnya bahwa rock phosphate dan dolomit memiliki efek pengapuran bagi tanah, peningkatan $\mathrm{pH}$ karena aplikasi dua mineral tersebut diduga mampu menurunkan potensi ikatan dari $\mathrm{P}$ menjadi Al-P dan Fe-P (Tan, 2000) untuk membentuk pool $\mathrm{P}$ yang stabil di dalam tanah. Kombinasi dari efek pengapuran dan pemupukan $\mathrm{P}$ dilaporkan pada beberapa penelitian sebelumnya berpotensi untuk mendukung rehabilitasi tanah Ultisol dan meningkatkan efisiensi pemupukan $P$ (Shamshuddin et al., 1992; Wijanarko \& Taufiq, 2008; Yang et al., 2012).

Menariknya, pada studi ini, ketersedian $\mathrm{P}$ pada perlakuan dolomit terlihat serupa dengan kontrol. Hal tersebut mengindikasikan bahwa perbaikan $\mathrm{pH}$ melalui aplikasi dolomit tidak mendorong transformasi dari sebagian fraksi P stabil menjadi $\mathrm{P}$ dengan ikatan yang lemah. Selain itu, tidak ada perubahan yang cukup besar terjadi pada $\mathrm{P}$ tersedia di topsoil. Hal ini dikarenakan sangat kecilnya kuantitas dari $\mathrm{P}$ pada larutan tanah dibandingkan dengan total $\mathrm{P}$ (Holford et al., 1998) serta afinitas $\mathrm{P}$ untuk dipertahankan oleh partikel tanah, sehingga pergerakan $\mathrm{P}$ melalui pelindian hampir dapat diabaikan (Sims et al., 1998 ; Rahutomo \& Ginting, 2018).

\section{Distribusi Akar Tanaman Kelapa Sawit}

Aplikasi rock phosphate (perlakuan RP) menghasilkan total bobot kering akar primer kelapa sawit tertinggi dibandingkan perlakuan lainnya (Gambar 2). Rock phosphate mengandung sejumlah fosfor yang merupakan hara makro esensial bagi pertumbuhan tanaman. Fosfor merupakan penyusun dari asam nukleat, DNA, RNA, ATP, phospholipids serta sel membran yang memiliki peran krusial dalam metabolisme energi dan stimulator pertumbuhan tanaman (Péret et al., 2011; Shen et al., 2011; Kim \& Li, 2016; Campos et al., 2018). Oleh karena itu, pertumbuhan vegetatif tanaman, terutama akar muda sangat dipengaruhi oleh distrubusi dan ketersediaan Fosfor dalam tanah (Buddh, 2014).

Hal tersebut sesuai dengan hasil penelitian dimana distribusi dari akar primer lebih besar pada tanah lapisan bawah dengan 30\% dari distribusi ditemukan pada lapisan $0-20 \mathrm{~cm}$ dan $70 \%$ pada lapisan 20-40 cm. Hasil serupa dilaporkan oleh Pradiko dkk. (2016) dimana kerapatan akar dengan nilai terbesar ditemukan pada kedalaman 20-40 cm. Akar primer umumnya lebih banyak ditemukan pada kedalaman tanah $>20 \mathrm{~cm}$ yang juga bersifat othogravitropic dengan kemampuan distribusi vertikal yang tinggi sesuai dengan perannya dalam mendukung pertumbuhan tanaman, dan penyerapan air (Jourdan et al., 2000; Albertazzi et al., 2009; Marwanto dkk., 2012). Lebih lanjut, $\mathrm{Ng}$ et al. (2003) dan Intara et al. (2018) melaporkan bahwa akar primer tanaman kelapa sawit dapat tumbuh secara vertikal hingga kedalaman $200 \mathrm{~cm}$.

Total berat kering akar sekunder tertinggi $\left(1,34 \mathrm{~g} / \mathrm{dm}^{3}\right)$ ditemukan pada perlakuan RP. Distribusi vertikal dari akar sekunder pada kedalaman 0-20 cm cenderung lebih rapat dibandingkan kedalaman 20-40 cm, dengan proporsi masing-masing 65\% dan 35\%. Sementara itu, total berat kering tertinggi untuk akar tersier (2,19 gram $/ \mathrm{dm}^{3}$ ) diketahui berada pada aplikasi D+RP. Serupa halnya dengan akar sekunder, distribusi dari 
akar tersier lebih dominan pada lapisan 0-20 cm dibandingkan dengan lapisan 20-40 cm. Distribusi dominan dari akar sekunder dan tersier dilaporkan oleh Marwanto dkk. (2012) dan Pradiko dkk. (2016).

Lebih tingginya komposisi akar sekunder dan tersier di lapisan tanah bagian atas dibanding akar primer diduga ada kaitannya dengan fungsi masing-masing jenis akar. Akar sekunder dan akar tersier lebih berperan dalam penyerapan hara, dimana hara dari pemupukan ataupun mineralisasi bahan organik lebih banyak ditemukan terakumulasi pada lapisan tanah atas (topsoil).
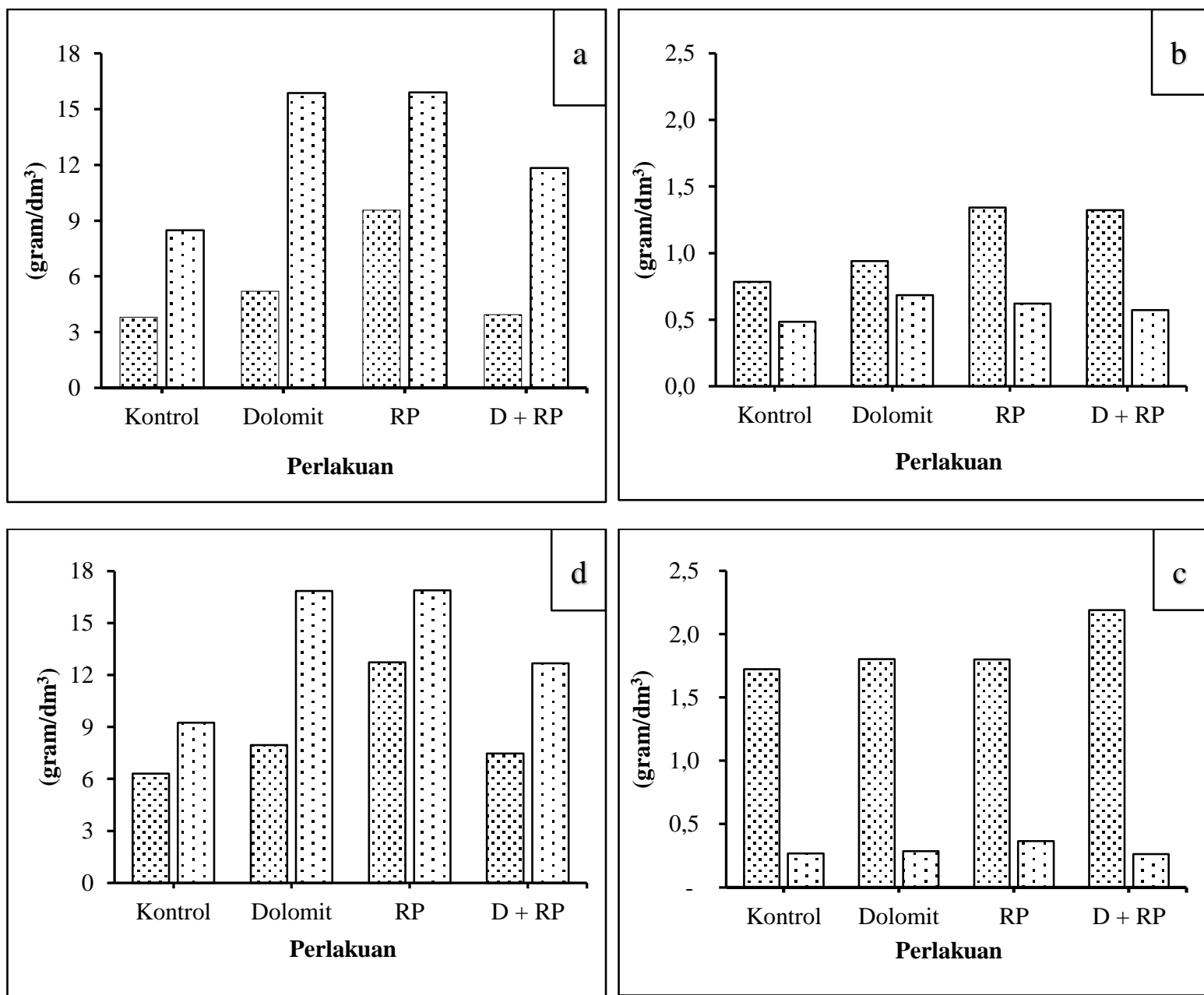

Keterangan: - kedalaman tanah 0-20 cm; = kedalaman tanah $20-40 \mathrm{~cm}$

Gambar 2. Distribusi akar kelapa sawit pada kedalaman tanah 0-20 cm dan 20-40 cm. (a) akar primer. (b) Akar sekunder. (c) Akar tersier. (d) Jumlah akar total.

Akar sekunder dan tersier ditemukan lebih padat dan rapat pada topsoil karena akar ini berperan penting guna mengeksploitasi serapan hara. Marwanto dkk. (2012) mendukung temuan tersebut dengan menjelaskan bahwa kandungan hara yang lebih tinggi pada topsoil berdampak positif pada kerapatan dari akar tersier dan kuarter pada lapisan subsoil. Pada studi lainnya, Putri (2015) menyatakan bahwa kerapatan akar pada kedalaman tanah 0-30 $\mathrm{cm}$ di areal piringan (areal untuk aplikasi pupuk) dan gawangan mati/rumpukan pelepah $(>4,5 \mathrm{~m}$ dari batang tanaman, areal terjadinya mineralisasi dari proses dekomposisi pelepah) bernilai cukup serupa. Hal tersebut merupakan dasar yang mendukung bahwa kecukupan hara merupakan faktor yang mendukung pertumbuhan akar tanaman kelapa sawit (Kheong et al., 2010).

Distribusi akar secara horizontal berdasarkan jaraknya dari pangkal pohon disajikan pada Gambar 3. Secara horizontal, akar primer, sekunder, dan tersier umumnya memiliki distribusi dominan pada jarak 0-1 meter dari pangkal pohon, semakin jauh jarak dengan pohon maka pola kerapatan akar semakin menurun. Hasil penelitian serupa juga dilaporkan oleh Pradiko dkk. (2016), 
dimana distribusi dari akar tanaman kelapa sawit ditemukan paling banyak pada radius $150 \mathrm{~cm}$ dari pangkal pohon dan berkurang secara bertahap seiring penambahan jarak dari batang tanaman. Pada penelitian lainnya, Marwanto dkk. (2012) menyatakan hal yang sama, dimana kerapatan akar pada jarak dekat lebih tinggi dibandingkan jarak 4,5 m dari batang tanaman kelapa sawit.

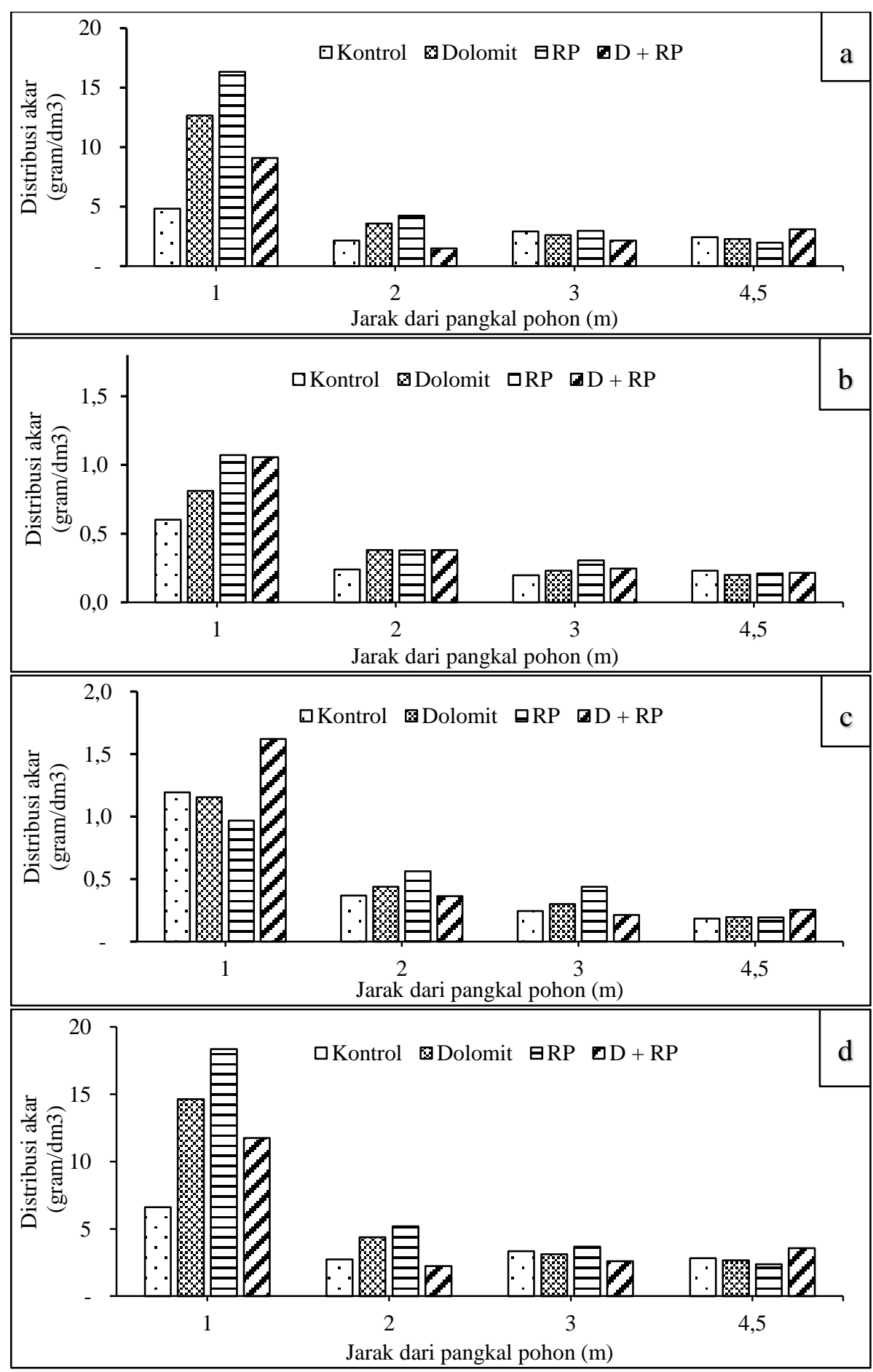

Gambar 3. Distribusi akar kelapa sawit secara horizontal. (a) Akar primer. (b) Akar sekunder. (c) Akar tersier. (d) Jumlah akar total.

Gambar 3 turut menunjukkan bahwa perlakuan RP menghasilkan kerapatan akar yang secara signifikan lebih tinggi dari perlakuan lainnya.
Peningkatan kerapatan akar dengan meningkatnya ketersedian fosfor pada perlakuan RP, menunjukkan keeratan kaitannya dengan fungsi fosfor sebagai 
pendukung pertumbuhan dan perkembangan tanaman, juga perannya dalam pembentuk senyawa yang mentransfer energi seperti ATP dan ADP (Lambers \& Plaxton, 2015).

Adanya pola kerapatan akar yang semakin menurun dengan bertambahnya jarak dari pangkal batang juga semakin membuktikan bahwa akar kelapa sawit terbukti dapat beradaptasi dengan baik terhadap distribusi lateral unsur hara (Marwanto dkk., 2012). Aplikasi pemupukan yang telah dilakukan sejak tanaman pertama kali ditanam hingga tanaman berumur 19 tahun secara langsung telah membentuk pola sebaran perakaran tanaman kelapa sawit. Aplikasi pemupukan yang dilakukan secara konsisten pada piringan pohon $( \pm 2,5 \mathrm{~m}$ dari pangkal batang) menyebabkan kerapatan akar dan konsentrasi unsur hara di dekat batang kelapa sawit memiliki nilai tertinggi dan kemudian menurun dengan bertambahnya jarak dari pangkal batang.

\section{Analisis Hara Akar}

Selain analisis tanah, dalam penelitian ini juga dilakukan analisis akar untuk mengetahui kadar hara N, P, K, dan Mg di dalam akar. Hasil penelitian memperlihatkan bahwa secara umum kadar hara $\mathrm{P}$, $\mathrm{K}$, dan $\mathrm{Mg}$ akar tertinggi diperoleh pada perlakuan aplikasi rock phosphate, kecuali hara $\mathrm{N}$ dimana kadar tertinggi diperoleh pada perlakuan kontrol (Tabel 2). Sejalan dengan pola hasil analisis tanah (Tabel 1), hasil analisis akar yang berada pada lapisan 0-20 $\mathrm{cm}$ lebih tinggi dibandingkan lapisan 20-40 cm (Tabel 3). Kondisi ini sejalan dengan pola penyebaran akar seperti yang telah dijelaskan sebelumnya bahwa secara umum sebaran akar sekunder dan tersier relatif lebih banyak pada lapisan 0-20 cm (topsoil) dibandingkan dengan 20$40 \mathrm{~cm}$ (subsoil). Hal ini semakin memperkuat fakta bahwa ketersediaan hara sangat mempengaruhi kerapatan akar.

Tabel 2. Kadar hara N, P, K, dan Mg akar tanaman kelapa sawit pada masing-masing perlakuan*)

\begin{tabular}{lcccc}
\hline Perlakuan & $\mathrm{N}(\%)$ & $\mathrm{P}(\%)$ & $\mathrm{K}(\%)$ & $\mathrm{Mg}(\%)$ \\
\hline Kontrol & 0,58 & 0,03 & 0,68 & 0,04 \\
Dolomit & 0,51 & 0,03 & 0,68 & 0,06 \\
RP & 0,55 & 0,04 & 0,71 & 0,06 \\
RP + Dolomite & 0,51 & 0,03 & 0,63 & 0,05 \\
\hline
\end{tabular}

Keterangan: ${ }^{*}$ ) kadar hara akar merupakan jumlah total dari kadar hara akar primer, sekunder, dan tersier pada semua jarak dan kedalaman.
Selanjutnya, kadar hara akar yang lebih tinggi pasca aplikasi rock phosphate dibandingkan perlakuan lain menunjukkan bahwa rock phosphate mampu memperbaiki $\mathrm{pH}$ dan ketersediaan hara. Peningkatan ketersediaan hara tanah, khususnya $\mathrm{P}$ (fosfor) akan merangsang pertumbuhan akar. Hal ini karena fosfor merupakan hara yang berperan signifikan dalam perpanjangan akar dan proliferasi (Niu et al., 2013). Umumnya penyerapan fosfor paling aktif ditemukan pada apikal akar baru karena terdapat protein transportasi hara yang mampu meningkatkan serapan hara P pada akar (Mikkelsen, 2013).

Tabel 3. Kadar hara total akar pada masing-masing perlakuan pada tiap kedalaman

\begin{tabular}{lrccc}
\hline \multirow{2}{*}{ Perlakuan } & \multicolumn{4}{c}{ Kadar Hara (\%) } \\
\cline { 2 - 5 } & $\mathrm{N}$ & $\mathrm{P}$ & $\mathrm{K}$ & $\mathrm{Mg}$ \\
\hline \multirow{3}{*}{ Kontrol } & -----------0 & $20 \mathrm{~cm}$ & --------- \\
Dolomit & 0,600 & 0,036 & 0,707 & 0,043 \\
RP & 0,583 & 0,034 & 0,700 & 0,077 \\
RP + Dolomit & 0,543 & 0,038 & 0,753 & 0,077 \\
\hline \multirow{4}{*}{ Kontrol } & ---------20 & 0,560 & 0,077 \\
Dolomit & 0,553 & 0,029 & 0,643 & 0,027 \\
RP & 0,397 & 0,031 & 0,667 & 0,043 \\
RP + Dolomit & 0,523 & 0,035 & 0,670 & 0,050 \\
& 0,480 & 0,027 & 0,697 & 0,030 \\
\hline
\end{tabular}

Aplikasi rock phosphate dan dolomit umum dilakukan pada perkebunan kelapa sawit terutama pada tanah yang cukup masam dan kandungan hara rendah seperti tanah Ultisol (Nurjaya dkk., 2009). Rendahnya kandungan hara terutama fosfor $(\mathrm{P})$ pada grup Tanah Ultisols disebabkan oleh rendahnya sumber fosfat dalam tanah, serta fiksasi hara oleh mineral Al dan $\mathrm{Fe}$ (Wijanarko \& Taufiq, 2008; Syahputra dkk., 2015). Pada tanaman kelapa sawit, penambahan Rock Phosphate mampu memperbaiki sifat kimia tanah Ultisol seperti peningkatan $\mathrm{pH}$, $\mathrm{KTK}, \mathrm{KB}$, dan hara terutama $\mathrm{P}$ juga berdampak positif pada peningkatan produksi (Siahaan \& Darmosarkoro, 2007).

\section{SIMPULAN}

Hasil penelitian menunjukkan bahwa aplikasi rock phosphate mampu meningkatkan $\mathrm{pH}$ tanah. Aplikasi RP juga meningkatkan kandungan P tanah serta merangsang lebih berkembangnya sistem perakaran dibandingkan perlakuan lainnya. 


\section{DAFTAR PUSTAKA}

Abat, M, MJ McLaughlin, JK Kirby, and SP Stacey. 2012. Adsorption and desorption of copper and zinc in tropical peat soils of Sarawak, Malaysia. Geoderma. 175-176: 58-63.

Adorolo, MO, BO Okonokhua, and EA Akinrinde. 2015. Comparative effects of lime and phosphorus sources on nutrients uptake and yield of maize in a tropical Ultisol. International Journal of Plant \& Soil Science. 4(2): 140-48.

Albertazzi, H, CMI Chinchilla, and F Ramirez. 2009. Soil characteristics and root development in young oil palms (Elaeis guineensis Jacq.) planted in sites affected by bud rots (pudrición del cogollo). ASD Oil Palm Papers (Costa Rica). 33: 1-14.

Anggraini, D, F Barchia, dan Y Erfieni. 2009. Hubungan berat tandan buah segar kelapa sawit dengan $\mathrm{Ca}, \mathrm{Mg}$, dan KTK pada tanah Ultisol Bengkulu. Akta Agrosia. 12: 173-76.

Blume, HP, GW Brümmer, H Fleige, R Horn, E Kandeler, I Kögel-Knabner, R Kretzschmar, K Stahr, and BM Wilke. 2015. Scheffer/Schachtschabel Soil Science. Springer.

Boroomand, N, and MSH Grouh. 2012. Macro elements nutrition (NPK) of medical plants. Journal of Medical Plant Research. 6: 22492255.

Buddh, S. 2014. Comparative study of rock phosphate and calcium phosphate on the growth and biochemistry of Brassica Juncea and it's impact on soil health. IOSR Journal of Environmental science, Toxicology and Food Technology. 8(11): 22-39.

Campos, P, F Borie, P Cornejo, JA López-Ráez, A López-García, and A Seguel. 2018. Review: Phosphorus acquisition efficiency related to root traits: Is mycorrhizal symbiosis a key factor to wheat and barley cropping?. Frontiers in Plant Science. 9(752): 1-21.

Danso, I, BN Nuertey, TEO Asamoah, FM Tetteh, F Danso, PA Afari, EY Safo, and V Logah. 2010. The effect of rock phosphate on soil nutrient dynamics, growth, development and yield of oil palm in the semi-deciduous forest zone of Ghana. Journal of science and technology. 30(1): 30-44.

Dubrovsky, JG, and M Laskowski. 2017. Lateral root initiation. In Pp. 256-264. Encyclopedia of Applied Plant Sciences (B Tomas, BG
Murray, DG Murphy, Eds). $2^{\text {nd }}$ Ed. Academic Press. Oxford.

El Zrelli, R, L Rabaoui, N Daghbouj, H Abda, S Castet, C Josse, $\mathrm{P}$ van Beek, M Souhaut, S Michel, N Bejaoui, and P Courjault-Rade. 2018. Characterization of phosphate rock and phosphogypsum from Gabes phosphate fertilizer factories (SE Tunisia): high mining potential and implications for environmental protection. Environmental Science Pollution Research International. 25(15):14690-14702.

Evert, RF. 2006. Esau's Plant Anatomy, Meristems, Cells, and Tissues of the Plant Body: Their Structure, Function, and Development. $3^{\text {rd }}$ Ed. John Wiley and Sons. New Jersey.

Fitriatin, BN, A Yuniarti, T Turmuktini, and FK Ruswandi. 2014. The effect of phosphate solubilizing microbe producing growth regulators on soil phosphate, growth and yield of maize and fertilizer efficiency on Ultisol. Eurasian Journal of Soil Science. 3: 101-107.

Gao, H, J Bai, Q Wang, L Huanga, and R Xiao. 2010. Profile distribution of soil nutrients in unrestored and restored wetlands of the Yellow River Delta, China. Procedia Environmental Sciences 2: 1652-1661.

Husnain, S Rochayati, T Sutriadi, A Nassir, and M Sarwani. 2014. Improvement of soil fertility and crop production through direct application of phosphate rock on maize in Indonesia.Procedia Engineering. 83: 336343.

Intara, YI, AD Nusantara, Supanjani, Z Caniago, and $\mathrm{R}$ Ekawita. 2018. Oil palm roots architecture in response to soil humidity. International journal of oil palm. 1(2): 7989.

Jourdan, C, and R Hervé. 1997. Architecture and development of the oil-palm (Elaeis guineensis Jacq.) root system. Plant and soil. 189: 33-48.

Jourdan, C, N Michaux-Ferriere, and G Perbal. 2000. Root system architecture and gravitropism in the oil palm. Annals of Botany. 85: 861868.

Kheong, LV, ZA Rahman, MH Musa, and A Hussein. 2010. Empty fruit bunch application and palm root proliferation. Journal of Oil Palm Research. 22: 750-757.

Kim, HJ, dan X Li. 2016. Effect of phosphorus on shoot and root growth, partitioning, and 
phosphorus utilization efficiency in lantana. Hort Science. 51(8): 1001-1009.

Koh, LP, and DS Wilcove. 2008. Is oil palm agriculture really destroying tropical biodiversity? Conserv Lett 1: 60e4.

Lambers, H, and WC Plaxton. 2015. Phosphorus: back to the roots. In Pp. 1-22. Annual Plant Reviews Volume 48: Phosphorus Metabolism in Plants (WC Plaxton, H Lambers, Eds.). John Wiley and Sons. New Jersey.

Li, S, X Jiang, X Wang, and AL Wright. 2015. Tillage effects on soil nitrification and the dynamic changes in nitrifying microorganisms in a subtropical rice-based ecosystem: a longterm field study. Soil and Tillage Research. 150: 132-38.

Lynch, J. 2011. Root phenes for enhanced soil exploration and phosphorus acquisition: tools for future crops. J Plant Physiol. 156:1041-1049.

Marwanto, S, S Sabiham, U Sudadi, dan F Agus. 2012. Distribusi unsur hara dan perakaran pada pola pemupukan kelapa sawit di dalam piringan di Kabupaten Muaro Jambi, Provinsi Jambi. Prosiding Seminar Nasional Teknologi Pemupukan Dan Pemulihan Lahan Terdegradasi. Bogor. Hlm. 213-24.

Mikkelsen, R. 2013. A Closer Look at Phosphorus Uptake by Plants. Available online at http://www.ipni.net/publication/insightsna.nsf/0/324D239E9065F43385257CD80076 5F01. Accessed February 2020.

$\mathrm{Ng}$, SK, H Von Uexkull, and H Rolf. 2003. Botanical aspects of oil palm relevant to crop management. In Pp. 14-15. The Oil palm Management for Large and Sustainable Yields (T Fairhust, R Hardfer, Eds.). Potash and Phosphate Institute (PPI), Potash and Phosphate Institute of Canada (PPIC), and International Potash Institute (IPI). Basel.

Niu, YF, R-S Chai, G-L Jin, H Wang, C-X Tang, and Y-S Zhang. 2013. Responses of root architecture development to low phosphorus availability: a review. Annals of Botany. 112: 391-408.

Nurjaya, A Kasno, dan A Rachman. 2009. Pemanfaatan fosfat alam untuk tanaman perkebunan. Dalam Fosfat Alam: Pemanfaatan Fosfat Alam yang Digunakan Langsung Sebagai Pupuk Sumber P. Balai Penelitian Tanah Badan Penelitian dan
Pengembangan Pertanian. Departemen Pertanian Bogor. Bogor. Hlm. 105-117.

Nyoki, D, and PA Ndakidemi. 2018. Selected chemical properties of soybean rhizosphere soil as influenced by cropping systems, rhizobium inoculation, and the supply of phosphorus and potassium after two consecutive cropping seasons. International Journal of Agronomy. 1-8.

Péret, B, M Clément, L Nussaume, and T Desnos. 2011. Root developmental adaptation to phosphate starvation: better than sorry. Trends in Plant Science. 16(8): 442-450.

Pradiko, I, F Hidayat, NH Darlan, H Santoso, Winarna, S Rahutomo, dan ES Sutarta. 2016. Distribusi perakaran kelapa sawit dan sifat fisik tanah padsa ukuran lubang tanam dan aplikasi tandan kosong sawit yang berbeda. J. Pen. Kelapa Sawit. 24(1): 23-38.

Putri, V. 2015. Oil Palm (Elaeis guineensis) root growth in response to different fertilization practices. Master Thesis, Wageningen University and Research Centre.

Ralisch, R, and C De Conti. 2012. Soil physical properties and sugarcane root in a red Oxisol. R. Bras. Ci. Solo. 36(1): 63-70.

Rahutomo, S, and EN Ginting. 2018. Leaching levels of $\mathrm{N}, \mathrm{P}, \mathrm{K}$, and $\mathrm{Mg}$ from application of several types of fertilizers. Journal of Oil Palm Research. 26(1):37-47.

Redzuan, AF, I Arifin, R Ishak, NA Rasid Mohd, and S Hamzah. 2013. Assessment on the use of highly reactive phosphate rock for immature palms. International Proceedings of Chemical, Biological and Environmental Engineering (IPCBEE) 2013 Vol. 60 pp. 3842 ref.10. International Conference on Agriculture and Biotechnology. Kuala Lumpur Malaysia 29-30 December 2013.

Ren, B, X Li, S Dong, P Liu, B Zhao, and J Zhan. 2018. Soil physical properties and maize root growth under different tillage systems in the North China Plain. The Crop Journal. 6: 669-676.

Shamshuddin, J, I Jamilah, HAH Sharifuddin, and LC Bell. 1992. Limestone, gypsum, palm oil mill effluent and rock phosphate effects on soil solution properties of some Malaysian Ultisol and Oxisols. Pertanika. 15(3): 225235.

Shen, J, L Yuan, J Zhang, H Li, Z Bai, X Chen, W Zhang, and F Zhang. 2011. Phosphorus 
dynamics: from soil to plant. Plant Physiology. 156: 997-1005.

Sims, JT, RR Simard, and BC Joern. 1998. Phosphorus loss in agricultural drainage: historical perspective and current research. Journal of environmental Quality. 31: 319330.

Holford, ICR. 1997. Soil phosphorus: its measurement, and its uptake by plants. Australian Journal of Soil Research. 35(2): 227-39.

Shamshuddin, J, IC Fauziah, and LC Bell. 2009. Effect of dolomitic limestone and gypsum applications on soil solution properties and yield of corn and groundnut grown on Ultisol. Malaysian Journal of Soil Science. 13: 1-12.

Siahaan, MM, dan W Darmosarkoro. 2007. Uji banding beberapa jenis fosfat alam terhadap pertumbuhan dan produksi tanaman kelapa sawit. Dalam Lahan dan Pemupukan Kelapa Sawit. Pusat Penelitian Kelapa Sawit (PPKS). Medan.

Sipayung, ES, G Sitanggang, dan MMB Damanik. 2014. Perbaikan sifat fisik dan kimia tanah Ultisol Simalingkar, Kecamatan Pancur Batu dengan pemberian pupuk organik supernasa dan rockphosphit serta pengaruhnya terhadap produksi tanaman jagung (Zea mays 1.). Jurnal Online Agroekoteknologi. 2(2): 393-403.

Smith, RD, TJ Townsend, AWK Choy, ICW Hardy, and S Sjogersten. 2012. Short-term soil carbon sink potential of oil palm plantations. GCB Bioenergy. 4: 588-596.
Sun, C, H Cao, H Shao, X Lei, and Y Xiao. 2011. Growth and physiological responses to water and nutrient stress in oil palm. African Journal of Biotechnology. 10(51): 10465-71.

Sutarta, ES, Winarna, dan MA Yusuf. 2017. Distribusi hara dalam tanah dan produksi akar tanaman kelapa sawit pada metode pemupukan yang berbeda. Jurnal pertanian tropic. 4(1): 84-94.

Syahputra, E, Fauzi, dan Razali. Karakteristik sifat kimia sub group tanah Ultisol di beberapa wilayah Sumatera Utara. J. Agroekoteknologi. 4(1): 1796-1803.

Tan, KH. 2000. Environmental Soil Science. Marcel Dekker, Inc. New York. 360 p.

Wijanarko, A, dan A Taufiq. 2008. Pengaruh pemupukan fosfat dan dolomit pada kacang tanah di tanah Ultisol Banjarnegara. Prosiding Seminar Nasional Kacangkacangan dan Umbi-umbian tahun 2008. Tersedia online pada http://balitkabi.litbang.pertanian.go.id/wpcontent/uploads/2018/01/prosiding-200825-andy.pdf. Diakses Februari 2020.

Yahya, Z, A Husin, J Talib, J Othman, OH Ahmed, and MB Jalloh. 2010. Oil palm (Elaeis guineensis) roots response to mechanization in Bernam series soil. American Journal of Applied Science. 7(3): 343-348.

Yang, Y, Z He, X Yang, J Fan, P Stoffella, and C Brittain. 2012. Dolomite phosphate rockbased slow-release fertilizer for agriculture and landscapes. Communications in Soil Science and Plant Analysis. 43: 1344-1362. 